\title{
Plankton community structure and carbon cycling on the western coast of Greenland during the stratified summer situation. II. Heterotrophic dinoflagellates and ciliates
}

\author{
Henrik Levinsen ${ }^{1, *}$, Torkel Gissel Nielsen ${ }^{1}$, Benni Winding Hansen ${ }^{2}$ \\ ${ }^{1}$ National Environmental Research Institute, Department of Marine Ecology and Microbiology, Frederiksborgvej 399, \\ PO Box 358, DK-4000 Roskilde, Denmark \\ ${ }^{2}$ Roskilde University, Department of Life Sciences and Chemistry, PO Box 260, DK-4000 Roskilde, Denmark
}

\begin{abstract}
The structure and ecological role of protozooplankton (ciliates and heterotrophic dinoflagellates) were studied in Disko Bay, West Greenland, from mid-July to mid-September 1994. Heterotrophic dinoflagellates dominated the protozooplankton biomass. When diatoms formed subsurface blooms, heterotrophic dinoflagellates averaged $70 \%$ of the integrated protozooplankton biomass. After the diatoms declined, large heterotrophic dinoflagellates became less abundant. Ciliates followed the same vertical distribution as heterotrophic dinoflagellates. However, in contrast to heterotrophic dinoflagellates, maximum ciliate biomasses developed in surface water after the diatom blooms, when the large copepods (Calanus spp.) migrated to the deeper water. Mixotrophic oligotrich ciliates, mainly Laboea strobila, contributed on average $20 \%$ to the integrated ciliate biomass. Growth experiments revealed similar specific maximum growth rates for ciliates and heterotrophic dinoflagellates. Maximum growth rates were allometrically related to cell volume. Ciliates and heterotrophic dinoflagellates appear to be key organisms in the cycling of organic matter in this Arctic pelagic ecosystem.
\end{abstract}

KEY WORDS: Arctic pelagic food web - Protozooplankton structure - Ciliates - Heterotrophic dinoflagellates

\section{INTRODUCTION}

Ciliates and heterotrophic dinoflagellates are major microplankton (20 to $200 \mu \mathrm{m}$ size range) components; species in nanoplankton size (2 to $20 \mu \mathrm{m}$ ) may also contribute significantly to protozooplankton biomass and activity (Smetacek 1981, Sherr EB et al. 1986 , 1989, Sherr BF et al. 1989, Dolan 1991, Burkill et al. 1993, Verity et al. 1993). As constituents of the microbial food web, they have received much attention in plankton research during the past decades. Protozooplankton ingest particles too small to be efficiently utilized by copepods (Berggreen et al. 1988) and they are preyed upon by copepods (Stoecker \& Capuzzo 1990). This makes them key organisms in the carbon pathways (Azam et al. 1983). Several studies have docu-

•E-mail: hle@dmu.dk mented the significance of ciliates and heterotrophic dinoflagellates in temperate waters (Lessard et al. 1988, Montagnes et al. 1988, Riemann et al. 1990, Hansen 1991, Leakey et al. 1992). Only few data are available on their role in arctic waters. Andersen (1988) reported from the North Bering/Chukchi seas that $64 \%$ of the primary production was processed by the microbial food web at stations dominated by pico- and nanophytoplankton. At stations dominated entirely by diatoms, only $5 \%$ of the primary production was consumed by microbial grazers. However, heterotrophic dinoflagellates $>20 \mu \mathrm{m}$ which may have been important at the diatom-dominated stations were not examined. In another study from Disko Bay, conducted in connection with the spring bloom (Nielsen \& Hansen 1995), it was concluded that the grazing impact by the protozooplankton was 3 times higher than that of the copepods. Finally, Hansen et al. (1996) 
concluded that the community grazing by copepods was less important for the pelagic carbon flow than the microbial grazers in the Barents Sea.

Much literature on planktonic ciliates is restricted to biomass studies, relying on indirect estimates of in situ growth, such as extrapolation from laboratory-derived growth rates to calculate production (e.g. Burkill 1982, Leakey et al. 1992). Few measurements of 'natural' ciliate growth have been undertaken in marine waters, the majority of these focusing on tintinnids (Stoecker et al. 1983, Verity 1986, Gilron \& Lynn 1989) though measurements of oligotrichs have appeared recently (Leakey et al. 1994, Nielsen \& Kiørboe 1994, Pérez et al. 1997). Likewise, few studies have measured population growth rates of heterotrophic dinoflagellates under natural or semi-natural conditions (Bjørnsen \& Kuparinen 1991, Hansen et al. 1995, 1996). The studies of Bjørnsen \& Kuparinen (1991) and Hansen et al. (1996) are apparently the only reports of protozooplankton growth from cold-water ecosystems except for recent published growth rate estimates derived from population dynamics within sea ice from the Canadian High Arctic (Laurion et al. 1995, Sime-Ngando et al. 1997). Accordingly, more growth estimates from low temperatures are needed to support a concept of an actively growing protozooplankton community and important microbial food web in the Arctic.

The aim of this study was to evaluate the structure and trophic role of the nano- and micro-sized ciliates and heterotrophic dinoflagellates in an Arctic, pelagic ecosystem during the stratified ice-free period after the phytoplankton spring bloom. The data obtained are used in a comprehensive carbon flow model in the companion paper by Hansen et al. (1999, in this issue).

\section{MATERIALS AND METHODS}

Locality and sampling. The present investigation was conducted from July 17 to September 17, 1994, at a $250 \mathrm{~m}$ deep station located in Disko Bay on the west coast of Greenland, approximately 1 nautical mile off Qeqertarsuaq (Godhavn) (69 $15^{\prime} \mathrm{N}, 53^{\circ} 33^{\prime} \mathrm{W}$ ). The station was visited 18 times by RV 'Porsild' (Arctic Station, University of Copenhagen). On each occasion vertical profiles of chlorophyll a (chl a) fluorescence, temperature and salinity were recorded. From the vertical distribution of these parameters, 3 to 6 depths were sampled from the euphotic zone $(0$ to $30 \mathrm{~m})$. Water was collected with a Niskin bottle and transferred to a dark plastic container. All subsamples were taken from this container after mixing. Discrete sampling dates and depths for the euphotic zone are shown in Fig. 3. On a few occasions, samples were also collected below $30 \mathrm{~m}$.
Protozooplankton biomass and taxonomic composition. For identification and enumeration of all ciliates and of dinoflagellates $>20 \mu \mathrm{m}, 250 \mathrm{ml}$ samples were fixed in $2 \% \mathrm{v} / \mathrm{v}$ final concentration acid Lugol's solution. Samples were kept cold and dark until examination using an inverted microscope. Depending on the concentration of organisms, 50 or $100 \mathrm{ml}$ water, corresponding to at least 400 cells, was settled and counted using the Utermöhl technique. Identification of ciliates to species, group or morphotype was based on Leegaard (1915), Kahl (1932), Lynn et al. (1988), Lynn \& Montagnes (1988), Krainer \& Foissner (1990) and Lynn et al. (1991). Dinoflagellates were identified according to Drebes (1974), Dodge (1985) and Thomsen (1992). Unidentified spherical to subspherical gymnodinoid dinoflagellates were divided into size groups covering equivalent spherical diameter (ESD) size ranges of $10 \mu \mathrm{m}$ starting with ESD 20 to $30 \mu \mathrm{m}$. ESD and cell volume are related by: $\pi / 6 \times \mathrm{ESD}^{3}=$ cell volume.

Enumeration of heterotrophic dinoflagellates $<20 \mu \mathrm{m}$ and assessment of the ratio between unidentified autoand heterotrophic dinoflagellates $>20 \mu \mathrm{m}$ were made by epifluorescence microscopy using the appropriate exciter/barrier filter sets for blue ( 435 to $490 \mathrm{~nm}$ ) and UV (330 to $380 \mathrm{~nm}$ ) excitation. Two different fluorochromes and procedures for cells smaller and larger than $20 \mu \mathrm{m}$ were used as described below.

Heterotrophic dinoflagellates $<20 \mu \mathrm{m}$ were enumerated together with other nanoflagellates using a proflavine staining technique (Haas 1982). Duplicate water samples of $20 \mathrm{ml}$ were fixed in a mixture of $25 \%$ formaldehyde, $25 \%$ glutaraldehyde, demineralized water and a $15 \%$ solution of glucose $(1: 1: 2: 1 \mathrm{v} / \mathrm{v})$ to yield a final concentration of $2 \% \mathrm{v} / \mathrm{v}$. Before microscopical analysis, aliquots of 20 to $40 \mathrm{ml}$ were stained with $15 \mu \mathrm{l} 0.2 \mu \mathrm{m}$ pre-filtered proflavine $\mathrm{ml}^{-1}$, filtered onto $0.8 \mu \mathrm{m}$ black Nucleopore polycarbonate filters with a GF/C backing filter (vacuum $<2 \mathrm{~mm} \mathrm{Hg}$ ) and mounted with paraffin oil onto slides. The preparations were excited with blue light to visualize the redorange chlorophyll autofluorescence. Dinoflagellates $<20 \mu$ m were divided in the following size classes: ESD $6-10,11-14$ and $15-18 \mu \mathrm{m}$.

The ratio between $>20 \mu \mathrm{m}$ unidentified auto- and heterotrophic dinoflagellates in the $10 \mu \mathrm{m}$ size classes was assessed by using the fluorochrome DAPI (Porter \& Feig 1980). Aliquots of 50 to $200 \mathrm{ml}$ from glutaraldehyde fixed samples (final concentration $1 \% \mathrm{v} / \mathrm{v}$ ) were stained and prepared as described above. The filter preparations of 25 randomly selected samples were excited with blue light or UV light to visualize the characteristic blue-white dinoflagellate nuclei and red-orange chlorophyll autofluorescence, respectively. At least 75 cells were counted, most of these in the 20-30 $\mu \mathrm{m}$ size class. The ratio between auto- and het- 
erotrophic forms in this size class was assumed to be representative of the $30-40$ and $40-50 \mu \mathrm{m}$ size classes also. Naked unidentified dinoflagellates $>50 \mu \mathrm{m}$, presumably Gymnodinium/Gyrodinium spp., were considered as heterotrophic. The heterotrophic ratios obtained from the glutaraldehyde samples were multiplied with the dinoflagellate biomasses estimated from the Lugol fixed samples to determine the heterotrophic dinoflagellate biomass.

Biovolumes of all protozoans were estimated from linear dimensions using appropriate geometric shapes, and converted to biomass using conversion factors of $0.11 \mathrm{pg} \mathrm{C} \mathrm{m}^{-3}$ for ciliates and athecate dinoflagellates and $0.13 \mathrm{pg} \mathrm{C} \mathrm{mm}^{-3}$ for thecate dinoflagellates (Edler 1979). Length and width measurements of the ciliates were made in order to fit individuals into 1 of more than 100 morphotypes. Exceptions were Laboea strobila and some unidentified aloricate choreotrichs for which fixed length-width relationships were used (based on measurements of at least 30 individuals from different samples). For these ciliates only the length was measured. Dinoflagellates were measured and grouped according to the same rules as ciliates. For Gyrodinium spirale a fixed length-width relationship was used and only the length measured. No corrections were made for cell shrinkage due to fixation. Since variations in size and shape of the ciliate and dinoflagellate species often are considerable, some species may have been divided into more than 1 morphotype or group. Therefore, the number of ciliate morphotypes possibly overestimates the number of species actually present.

Mixotrophic ciliates. Due to loss of autofluorescence from glutaraldehyde fixed samples (as a result of prolonged storage time), only the obligate mixotrophic species Laboea strobila (McManus \& Fuhrman 1986), the potential mixotrophic Tontonia appendiculariformis (Laval-Peuto \& Febvre 1986) and Tontonia spp. were included in the estimation of mixotrophic contribution to the ciliate community. These species were all identified from Lugol samples.

Growth experiments. Protozooplankton maximum growth rates were calculated from changes in cell abundance in fractionated water samples mounted on a rotating plankton wheel ( $2 \mathrm{rpm})$. The plankton wheel was submerged in an opaque $1.5 \mathrm{~m}^{3}$ large PVC container covered with a lid and placed in a glacier stream $\left(1.4 \pm 0.6^{\circ} \mathrm{C}\right)$. A continuous flow of stream water through the container ensured that temperature remained constant. Irradiance inside the polycarbonate bottles was $26 \%$ of the incident light, corresponding to the light climate at $\sim 7.5 \mathrm{~m}$ depth at the sampling station.

Each experiment lasted $4 \mathrm{~d}$ and was as follows: duplicate $2.5 \mathrm{l}$ acid-washed polycarbonate bottles were filled with surface water or water collected from the subsurface chlorophyll maximum. The water was gently screened through a $160 \mu \mathrm{m}$ mesh by reverse filtration to remove larger predators. On Days 0, 1, 2 and 4, $250 \mathrm{ml}$ aliquots were fixed with acid Lugol's solution for later quantification.

Protozooplankton population or species maximum growth rates $(\mu)$ were calculated assuming exponential growth from: $\mu=\left(\ln N_{t 2}-\ln N_{11}\right) t^{-1}$, where $N_{12}$ and $N_{t 1}$ are the number of protozooplankton at time $t_{2}$ and $t_{1}$, respectively, and $t$ is the duration of incubation in days. Only species present with $>200$ ind. $\mathrm{l}^{-1}$ in the initial samples which increased were considered. Due to a decline in protozooplankton abundance between Day 0 and Day 1 , we excluded the $\mu_{0-1}$ growth estimates. Incubations with a general decline of organisms were also not included in the estimation of growth. Accordingly, species growth rates approximating maximum rates were calculated as a mean of all measurements on $\mu_{1-2}$ and $\mu_{2-4}$. These maximum growth rates were plotted against mean cell volumes of fixed specimens and a volume-growth rate relationship was established for both ciliates and heterotrophic dinoflagellates.

To examine whether or not chl a becomes depleted during incubations, triplicate $50 \mathrm{ml}$ water samples were filtered onto GF/C filters, extracted in $96 \%$ ethanol (Jespersen \& Christoffersen 1987) and measured on a Turner Designs fluorometer calibrated against spectrophotometrically determined chl a measurements. Phytoplankton growth rates $(\mu)$ were calculated as the mean of $\mu_{0-1}, \mu_{1-2}$ and $\mu_{2-4}$ according to the same equation as used for protozooplankton. Information on chlorophyll and temperature of the experimental water used for incubations is shown in Table 1.

Statistical tests. To test if the obtained protozoan maximum growth rates were different from the 'potential' rates (calculated by the multiple regression provided by Müller \& Geller 1993 ) at $T=1.4^{\circ} \mathrm{C}$, the slopes and intercepts of the 2 growth versus volume regression lines were compared. The regression line of the obtained relationship was estimated using a weighted least squares (WLS) regression with measurements of growth rates pooled into 1 weighted observation for each species. Using the inverse of the variance as weight for each species provides a best linear unbiased estimate (BLUE). The calculations were performed using SAS/PROC REG.

Production and grazing. Potential ciliate and heterotrophic dinoflagellate production were calculated as biomass times the volume-specific growth rates for each morphotype, using the volume-maximum growth rate relationships obtained in the growth experiments. Thus, potential community production of either the ciliates or the heterotrophic dinoflagellates was the sum of all the morphotype specific production estimates calculated in each sample ( $\Sigma$ biomass produced per 
morphotype). Potential ingestion was calculated from growth rates assuming complete heterotrophy and a carbon growth yield of $33 \%$ (Hansen et al. 1997). Both the production and the ingestion estimates therefore do not represent the actual rates at a given time but rather give information on the potential capacity of the ciliate and dinoflagellate community. Production and ingestion estimates were transformed from $1.4^{\circ} \mathrm{C}$ to in situ temperatures by using a $Q_{10}$ of 2.8 (Hansen et al. 1997). Biomass, production and ingestion per $\mathrm{m}^{2}$ were calculated by trapezoidal integration over the depth strata down to $30 \mathrm{~m}$ (Nielsen \& Bresta 1984). Integrated average ciliate and heterotrophic dinoflagellate concentration and biomass equal the integrated values divided by 30 .

\section{RESULTS}

\section{Hydrography and phytoplankton}

Disko Bay is influenced by fresh water from melting icebergs and runoff from land, resulting in a stratified water column from the time of the ice break and throughout the summer (Andersen 1981a,b). The main diatom bloom develops concurrently with the ice break and leaves the euphotic zone after the nutrients are depleted a few weeks later (Nielsen \& Hansen 1995). Accordingly, nutrient depleted and low salinity
Table 1. Water for growth incubations conducted in a stream at $1.4 \pm 0.6^{\circ} \mathrm{C}$ HNF: heterotrophic flagellates $<20 \mu \mathrm{m}$. (-) No chlorophyll fractionation measurements

\begin{tabular}{|rrrccc|}
\hline Date & $\begin{array}{c}\text { Depth } \\
(\mathrm{m})\end{array}$ & $\begin{array}{c}\text { Temperature } \\
\left({ }^{\circ} \mathrm{C}\right)\end{array}$ & $\begin{array}{c}\mathrm{HNF} \\
\left(\mu \mathrm{C} \mathrm{C} \mathrm{l}^{-1}\right)\end{array}$ & $\begin{array}{c}\text { Chlorophyll } \\
\left(\mu \mathrm{g} \mathrm{l}^{-1}\right)\end{array}$ & $\begin{array}{c}\text { Chlorophyll } \\
<11 \mu \mathrm{m}(\% \text { of total })\end{array}$ \\
\hline 7 Aug & 20 & 2.9 & 0.16 & 2.52 & - \\
$18 \mathrm{Aug}$ & 20 & 3.3 & 0.91 & 7.34 & - \\
27 Aug & 1 & 5.9 & 0.34 & 0.75 & 68 \\
1 Sep & 1 & 6.6 & 0.21 & 0.63 & 90 \\
& 15 & 5.0 & 1.03 & 0.72 & 83 \\
4 Sep & 1 & 6.1 & 0.32 & 0.81 & 56 \\
& 15 & 3.7 & 0.91 & 0.96 & 91 \\
6 Sep & 1 & 5.9 & 0.60 & 0.78 & 81 \\
& 20 & 4.3 & 0.61 & 1.14 & 89 \\
8 Sep & 1 & 5.1 & 0.40 & 0.63 & 62 \\
& 20 & 4.4 & 0.45 & 0.96 & 81 \\
\hline
\end{tabular}

surface water was partly separated from high salinity water rich in inorganic nutrients during the study period. The phytoplankton was dominated by nanosized cells except for 3 pronounced subsurface blooms associated with the pycnocline (Fig. 1). The first bloom was dominated by haptophytes and the subsequent blooms were dominated by chain-forming diatoms. For more details on hydrography, nutrients and primary producers see Nielsen \& Hansen (1999, in this issue).

\section{Protozooplankton composition and abundance}

The protozooplankton community was dominated by aloricate choreotrich ciliates and gymnodinoid dinoflagellates. Tintinnids, 'other' ciliates (haptorids, holotrichs, prostomatids) and thecate dinophysoid and peridinoid dinoflagellates were less frequently observed. Table 2 summarizes the identified genera, species and morphotypes.

The integrated average concentrations of ciliates and heterotrophic dinoflagellates $>20 \mu \mathrm{m}$ were of the same order of magnitude, ranging from 2 to 8 and 2 to 10 cells $\mathrm{ml}^{-1}$, respectively. If dinoflagellates $<20 \mu \mathrm{m}$ are included, the heterotrophic dinoflagellate concentration ranged from 3 to 17 cells $\mathrm{ml}^{-1}$ (Table 3). The highest concentration of ciliates was recorded on August 29 with values between 7 and 12 cells $\mathrm{ml}^{-1}$. Maximum concentrations of heterotrophic dinoflagellates $>20 \mu \mathrm{m}$ followed the diatom subsur-
Fig. 1. Vertical distribution of chl a $\left(\mu \mathrm{g} \mathrm{l}^{-1}\right)$ shown as shaded areas and water density $\left(\mathrm{kg}+1000 \mathrm{~m}^{-3}\right)$ calculated from salinity and temperature measurements (dots) shown as isolines with numbers. Chl a sampling depths are similar to protozooplankton sampling depths (see Fig. 3) 
Table 2. Protozooplankton identified from Disko Bay. Left column: ciliates; right column: heterotrophic dinoflagellates

\begin{tabular}{|l|l}
\cline { 2 - 2 } Oligotrichs & Athecate \\
Laboea strobila & Amphidinium crassum \\
Strombidium spp. & A. sphenoides \\
Tontonia appendiculariformis & Cochlodinium helix \\
Tontonia spp. & C.pulchellum \\
& Cochlodinium sp. \\
Naked choreotrichs & Gymnodinium gracile \\
Leegaardiella spp. & G.perparvum \\
Lohmaniella oviformis & G. rubrocinctum \\
Strobilidium spiralis & G. rubrum \\
Strobilidium spp. & Gymnodinium spp. \\
Strombidinopsis spp. & Gyrodinium crassum \\
& G. dominans \\
Tintinnids & G. spirale \\
Ptychocylis obtusa & Gyrodinium spp. \\
Parafavella denticulata & Katodinium glaucum \\
Eutintinnus tenuis & \\
Acanthostomella norvegica & Thecate \\
& Dinophysis rotundata \\
Others & Diplopsalis group \\
Askenasia spp. & Protoperidinium bipes \\
Balanion sp. & P. brevipes \\
Cyclotrichium sp. & P. depressum \\
Didinium sp. & P. pellucidum/pallium \\
Mesodinium rubrum & P. steinii \\
& Protoperidinium spp.
\end{tabular}

face blooms around August 3 and 18, with values of $>8$ and $>15$ cells $\mathrm{ml}^{-1}$ (data not shown).

\section{Biomass}

The integrated biomass of protozooplankton from the upper $30 \mathrm{~m}$ shows that heterotrophic dinoflagellate biomass generally was higher than ciliates during summer (July 17 to August 29), averaging 486 and $286 \mathrm{mg} \mathrm{C} \mathrm{m}{ }^{-2}$, respectively (Fig. 2B,C). In September, the ciliate biomass did not change significantly from summer values (Fig. 2B). Conversely the biomass of heterotrophic dinoflagellates decreased gradually to $47 \mathrm{mg} \mathrm{C} \mathrm{m}^{-2}$ at the last sampling (Fig. 2C). Generally, few species contributed to the bulk of the biomass, even though the diversity of protozooplankton was large. This was particularly true for the heterotrophic dinoflagellates where Gyrodinium spirale and Gymnodinium spp. $>50 \mu \mathrm{m}$ roughly contributed half of the biomass in July-August and $25 \%$ of the biomass in September. Laboea strobila was the major biomass contributor among the ciliates (see below).

The vertical distributions of ciliate and heterotrophic dinoflagellate biomass followed the phytoplankton with maximum values in subsurface waters associated with the pycnocline (Figs. 1 \& 3). This general trend was also shown by the most significant ciliate and dinoflagellate species (Fig. 3B,D) though the distribution pattern was more heterogenous for L. strobila. An important exception to the close relationship between the phytoplankton and protozooplankton was the observation of a ciliate maximum in surface waters during late August and the beginning of September after the subsurface bloom period. This ciliate biomass maximum developed following the downward migration of the large copepod species (Calanus spp.) to their deep-water hibernation refuge. Overall, a definitive depth trend was found

Table 3. Cell concentration and biomass ranges and mean values for major ciliate and heterotrophic dinoflagellate groups in Disko Bay (July to September). Values are integrated averages from 0 to $30 \mathrm{~m}$

\begin{tabular}{|c|c|c|c|c|}
\hline \multirow[t]{2}{*}{ Protozooplankton group } & \multicolumn{2}{|c|}{ Concentration (cells $\times 10^{3} \mathrm{l}^{-1}$ ) } & \multicolumn{2}{|c|}{ Biomass ( $\mu \mathrm{g} \mathrm{C}^{-1}$ ) } \\
\hline & Range & Mean & Range & Mean \\
\hline Mesodinium rubrum & $0.03-0.75$ & 0.28 & $0.02-1.23$ & 0.43 \\
\hline Tintinnids & $0.02-0.16$ & 0.05 & $0.02-0.74$ & 0.21 \\
\hline Heterotrophic oligo- and choreotrichs & $1.82-5.17$ & 3.30 & $2.20-9.63$ & 4.68 \\
\hline Mixotrophic oligotrichs ${ }^{\mathrm{a}}$ & $0.18-1.50$ & 0.66 & $0.73-11.8$ & 2.65 \\
\hline Others ${ }^{b}$ & $0.20-2.54$ & 1.13 & $0.27-2.41$ & 1.33 \\
\hline Total ciliates $^{c}$ & $2.32-8.22$ & 5.15 & $4.74-24.1$ & 8.87 \\
\hline Dinoflagellates $<20 \mu \mathrm{m}$ & $0.45-11.80$ & 3.55 & $0.01-1.16$ & 0.37 \\
\hline Dinoflagellates $>20 \mu \mathrm{m}$ & $2.13-10.37$ & 5.93 & $1.53-32.0$ & 12.70 \\
\hline Total heterotrophic dinoflagellates & $3.19-16.82$ & 9.48 & $1.57-32.6$ & 13.07 \\
\hline \multicolumn{5}{|c|}{$\begin{array}{l}\text { a Laboea strobila, Tontonia appendiculariformis and Tontonia spp. } \\
\text { bNumerically dominated by the small Balanion sp. } \\
{ }^{c} \text { Excluding M. rubrum }\end{array}$} \\
\hline
\end{tabular}



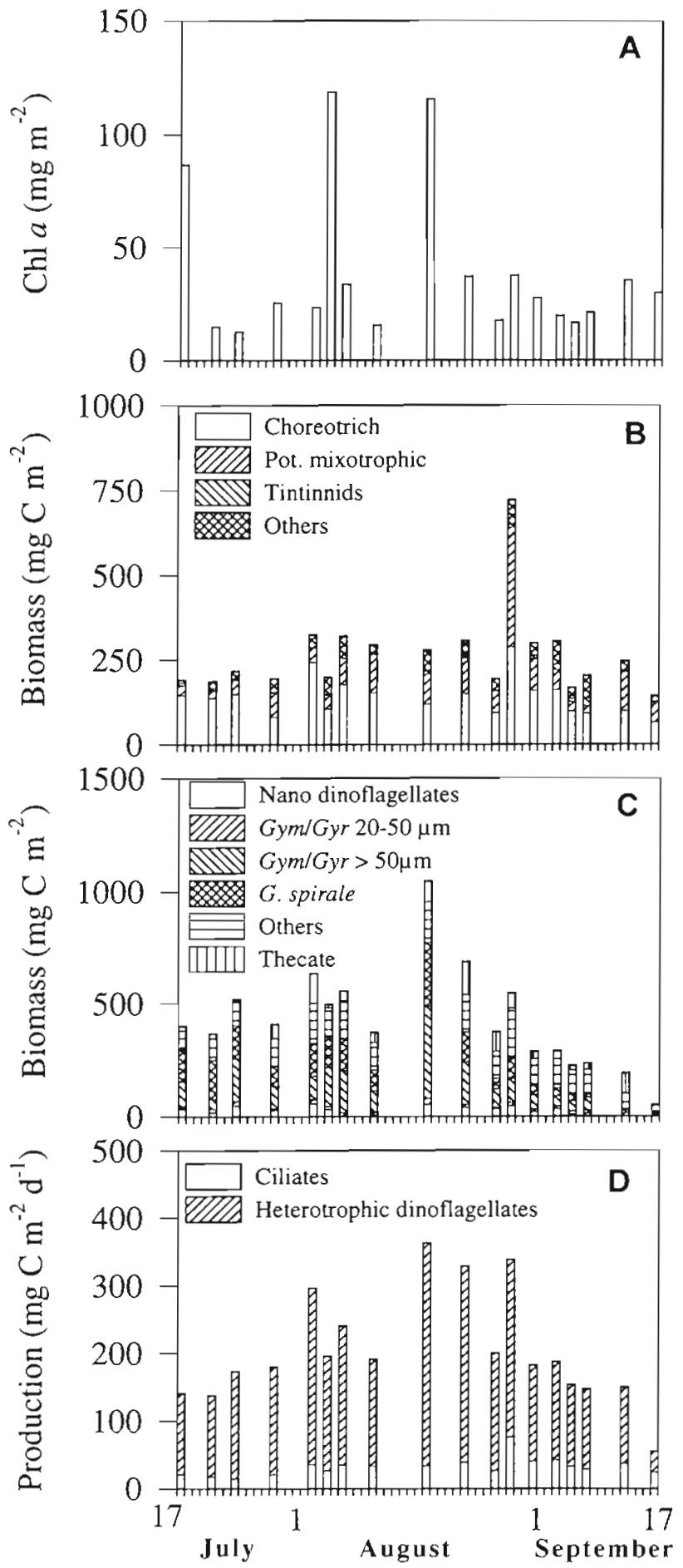

Fig. 2. Integrated biomass $(0$ to $30 \mathrm{~m}$ ) of (A) phytoplankton expressed as chl $a_{1}(B)$ ciliates, (C) heterotrophic dinoflagellates and (D) protozooplankton production $d^{-1}$ In (B), 'others' refers to non oligo- and choreotrichs. In (C), 'Gym/Gyr' refers to Gymnodinium spp. and Gyrodinium spp. with an equivalent spherical diameter (ESD) of 20 to 50 and $>50 \mu \mathrm{m}_{i}$ ' $G$. spirale' to Gyrodinium spirale; 'others' to Amphidinium spp., Gyrodinium spp.; and 'thecate' to Dinophysis rotundata, Diplopsalis group, Protoperidinium spp. Note the different scales

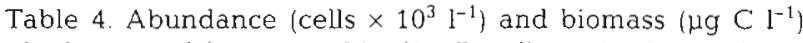
of ciliates and heterotrophic dinoflagel.ates in the euphotic zone $(0$ to $30 \mathrm{~m})$ and below during July to September 1994 (mean $\pm \mathrm{SD}$ )

\begin{tabular}{|c|c|c|c|c|}
\hline \multirow[t]{2}{*}{$\begin{array}{l}\text { Depth } \\
\text { (m) }\end{array}$} & \multicolumn{2}{|c|}{ Ciliates } & \multicolumn{2}{|c|}{$\begin{array}{l}\text { Heterotrophic } \\
\text { dinoflagellates }\end{array}$} \\
\hline & Abundance & Biomass & Abundanc & e Biomass \\
\hline Euphotic zone & $5.1 \pm 1.7$ & $8.9 \pm 4.3$ & $9.5 \pm 3.7$ & $13.1 \pm 6.9$ \\
\hline 50 & $2.1 \pm 0.7$ & $3.0 \pm 2.2$ & $1.3 \pm 0.9$ & $2.3 \pm 2.3$ \\
\hline 100 & $0.5 \pm 0.1$ & $0.4 \pm 0.1$ & $0.6 \pm 0.4$ & $0.5 \pm 0.2$ \\
\hline 150 & 0.6 & 0.3 & 0.9 & 0.5 \\
\hline 250 & 0.1 & 0.1 & 0.4 & 0.2 \\
\hline
\end{tabular}

during the study period, with decreasing abundance and biomass of ciliates and dinoflagellates below the euphotic zone (Table 4).

The autotrophic ciliate Mesodinium rubrum comprised an average of only 3 and $5 \%$ of the ciliate numbers and biomass, respectively. The integrated average abundance and biomass of this species peaked towards the autumn (Fig. 4A).

\section{Species succession}

Individual ciliate and heterotrophic dinoflagellate species had different temporal distribution patterns (Fig. 4). Some protozooplankton species had maximum occurrence in the first part of the study with a decline starting at the end of August and continuing during September. This pattern was shown by Gymnodinium/Gyrodinium spp. $>50 \mu \mathrm{m}$ (Fig. 4l). Other species had a biomass peak in mid-August. This was clearly demonstrated by the potential mixotrophic ciliate Tontonia spp., but also by Protoperidinium spp., Gymnodinium/Gyrodinium spp. 20-50 $\mu \mathrm{m}$ and Gyrodinium spirale (Fig. 4B, $\mathrm{K}, \mathrm{H}, \mathrm{J}$ ). A third group includes species which peaked in early autumn. These were Mesodinium rubrum, tintinnids and Balanion sp. (Fig. 4A,E, F). Finally, some protozooplankton species had no apparent temporal variation (Fig, 4C,D,G,L).

\section{Cell size distribution and relation to temperature}

The numerically dominant size group of ciliates consisted of species with an equivalent spherical diameter (ESD) $<20 \mu \mathrm{m}$. They contributed $40 \%$ of the ciliate abundance in the beginning of the study, increasing to $60 \%$ along with a decrease of ciliates $>30 \mu \mathrm{m}$. The relative contribution of ciliates between 20 and $30 \mu \mathrm{m}$ was constant (Fig. 5A). However, larger species (ESD $>40 \mu \mathrm{m})$ contributed most to the biomass. They accounted for $\sim 70 \%$ during July-August and 50 to 
$60 \%$ in September (Fig. 5B). All size groups were dominated by oligotrichs and choreotrichs, but 'other' ciliates occasionally contributed substantially to the biomass in the $\mathrm{ESD}>40 \mu \mathrm{m}$ size group. Heterotrophic dinoflagellates, like ciliates, were numerically dominated by smaller cells $(<30 \mu \mathrm{m})$. They also increased in number towards the end of the study, but in contrast to ciliates small heterotrophic dinoflagellate cells became significant in terms of biomass (Fig. 5C,D). A major change in the relative size distribution was observed following the decline of the 2 subsurface diatom blooms in August. Thus, the relative importance of larger $(>40 \mu \mathrm{m})$ heterotrophic dinoflagellates in terms of biomass decreased from $\sim 80$ to $<30 \%$.

The smallest ciliates recorded during this study were Strombidium-like cells with an ESD of $8 \mu \mathrm{m}$ (length $\times$ width $=12.5 \times 10 \mu \mathrm{m}$ ). The largest ciliates were Strombidinopsis sp. which had an ESD of $134 \mu \mathrm{m}$ (length $\times$ width $=165 \times 120 \mu \mathrm{m})$. Heterotrophic dinoflagellates also covered a wide cell size range, the smallest and largest species both belonging to the gymnodinoid type, with an ESD ranging from 8 to $110 \mu \mathrm{m}$. Thus, the interspecific variation in cell volume of protozooplankton species from Disko Bay covers at least 4 orders of magnitude.

Intraspecific variation in cell volume was correlated to temperature as illustrated by Laboea strobila and Gyrodinium spirale (Fig. 6). Linear regression analysis revealed slopes significantly different from zero $(\mathrm{p}<$ 0.03 and $\mathrm{p}<0.05$ for $L$. strobila and $G$. spirale, respectively). An analysis of residuals did not reveal deviations from assumptions involved in regression analysis.
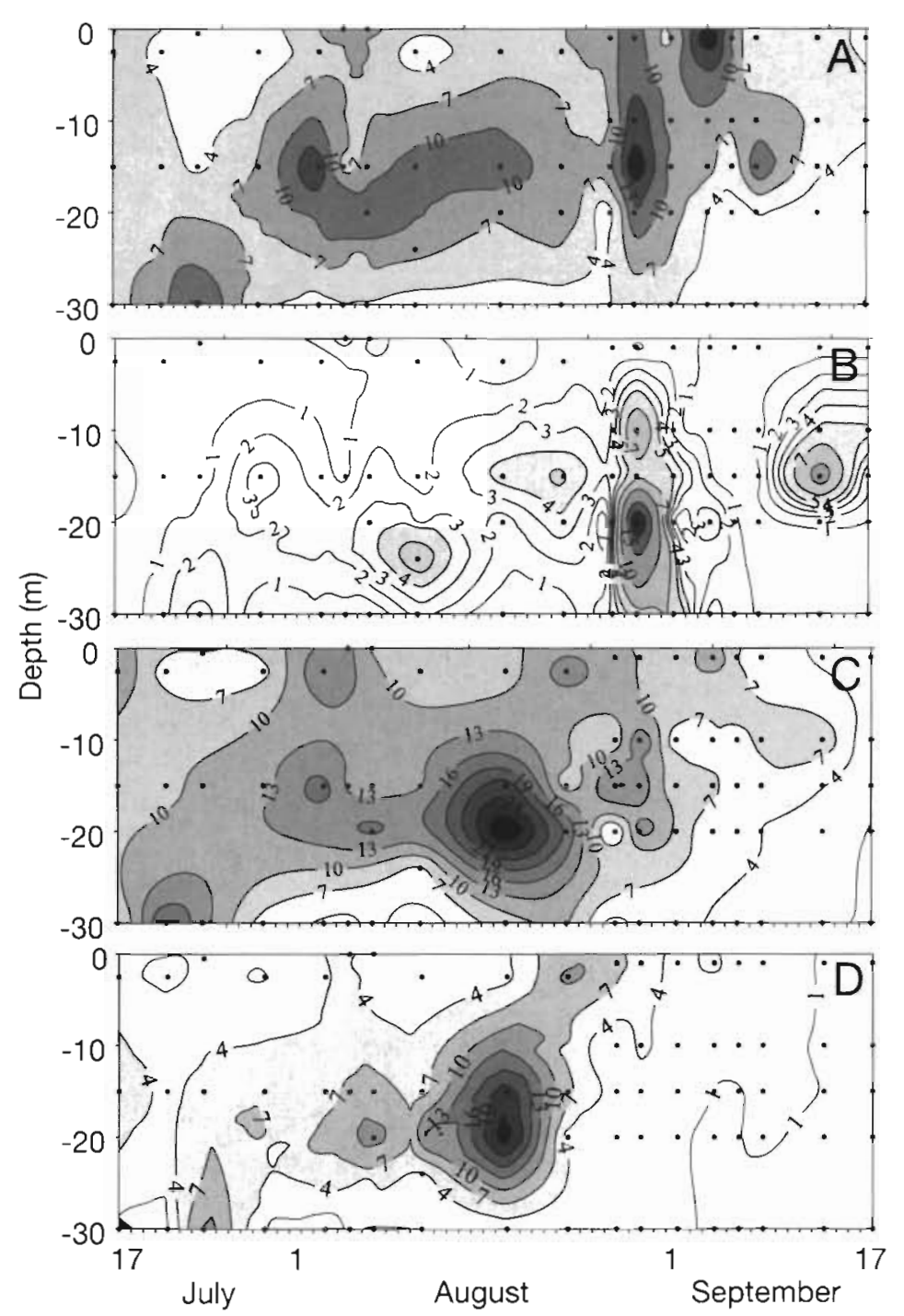

Fig. 3. Vertical distribution ( $\mu \mathrm{C} \mathrm{Cl}^{-1}$ ) of (A) mixo-heterotrophic ciliates excluding Laboea strobila, (B) L. strobila, (C) heterotrophic dinoflagellates excluding Gyrodinium spirale and (D) G. spirale. Dots indicate sampling depths

\section{Mixotrophy}

In the contribution of mixotrophic ciliates to the total ciliate community only Laboea strobila and the potential mixotrophic Tontonia spp. are included as such. Among the Tontonia spp., T. appendiculariformis was recognized as a known potential mixotrophic species. The other Tontonia morphotypes were not identified to species level. However, in this study they are all regarded as mixotrophic. L. strobila numerically accounted for $<10 \%$ of all ciliates. Due to its large cell size, the biomass contribution averaged $15 \%$ with a peak value of $42 \%$. A maximum biomass

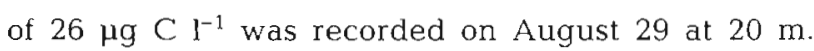
This high $L$. strobila occurrence coincided with elevated chl a values (Figs. 1 \& 3B). Tontonia spp., although numerically abundant, was always of minor importance in terms of biomass. Average integrated biomass never exceeded $1.3 \mu \mathrm{g} \mathrm{C} \mathrm{l}^{-1}$. Biomass had a unimodal distribution with a build up throughout the summer. In September, biomass rapidly declined (Fig. 4B). Together, L. strobila and Tontonia spp. contributed an estimated average of $20 \%$ ( 9 to $32 \%$ ) of the total ciliate biomass in the euphotic zone. No significant linear correlations were found between mixotrophic ciliate biomass and chl a or primary productivity (data not shown). 

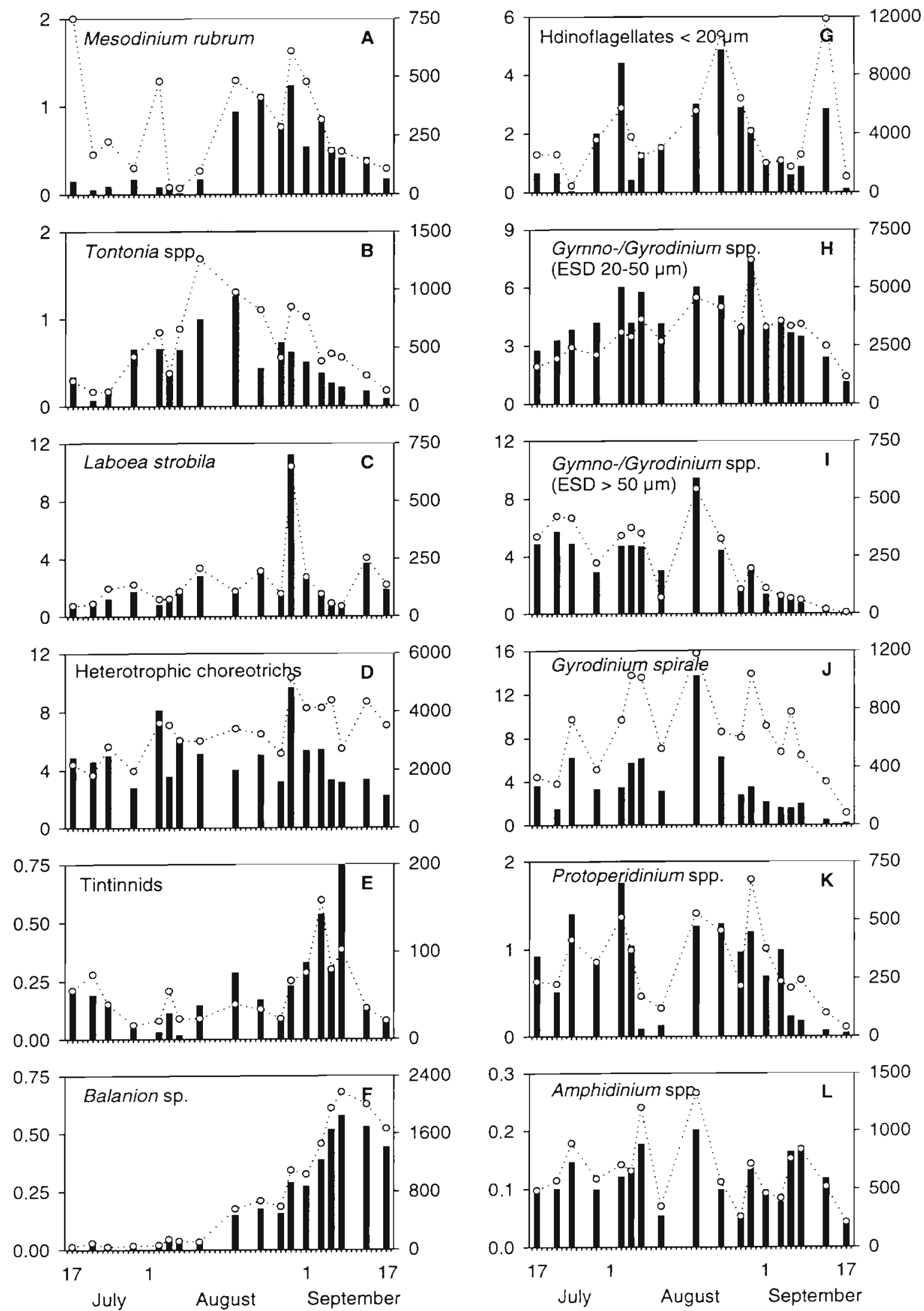

Fig. 4. Average biomass (left axis: $\mu \mathrm{g} \mathrm{Cl}^{-1}$, bars) and concentration (right axis: cells $\mathrm{l}^{-1}$, line) of ciliate and heterotrophic dinoflagellate species and size groups integrated for the euphotic zone $(0$ to $30 \mathrm{~m})$. Note different scales on $y$-axes 

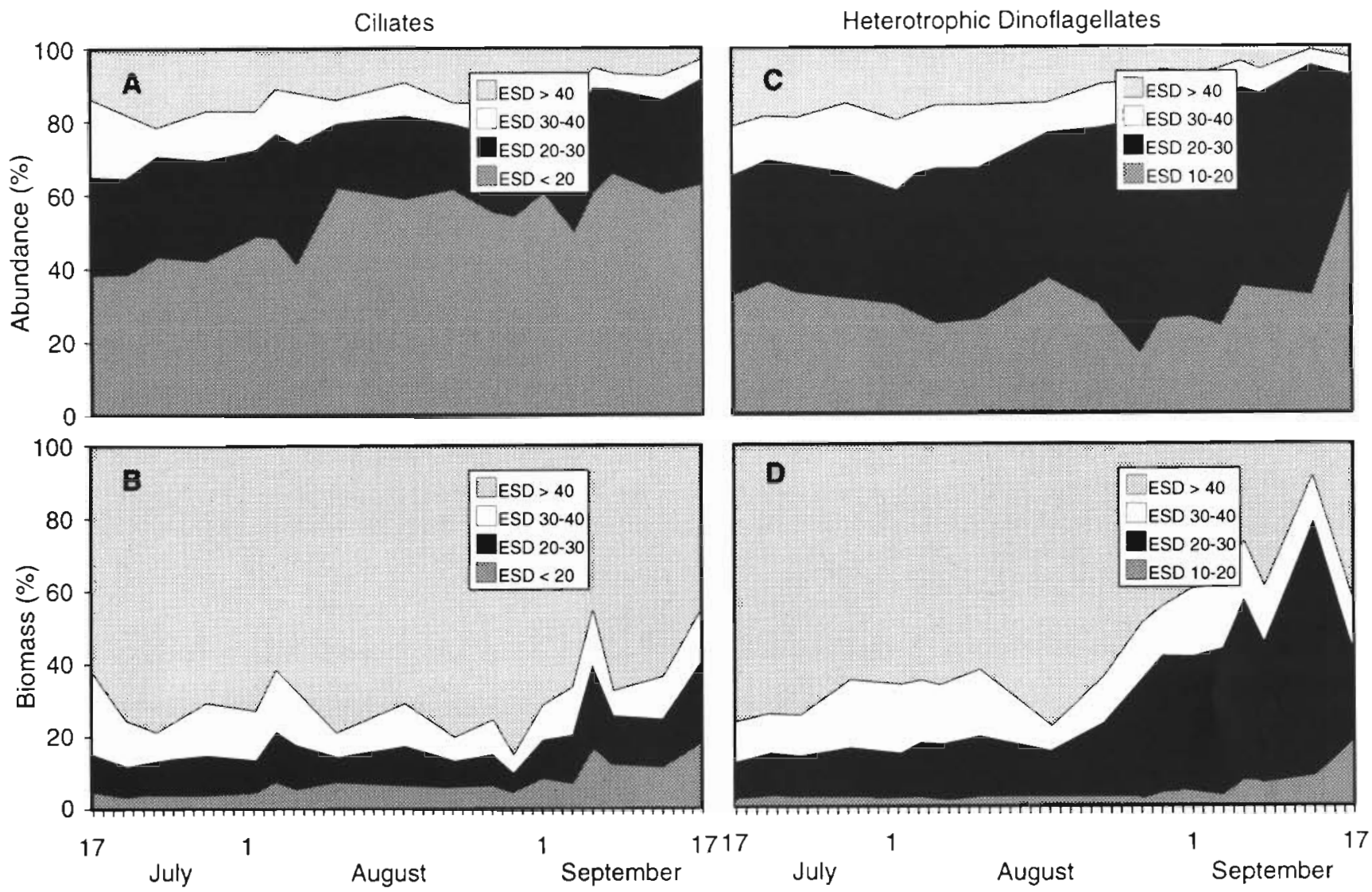

Fig. 5. Relative cell size distribution $(\mu \mathrm{m})$ of cluate and heterotrophuc dinoflagellate abundance $(A, C)$ and biomass $(B, D)$, respectively

\section{Growth and production}

The estimated maximum growth rates obtained for ciliates and heterotrophic dinoflagellates are pre-

Table 5 Growth of ciliates. Maxumum growth rate $\mathrm{d}^{-1}$ at $1.4^{\circ} \mathrm{C}(\mu)$, standard error (SE), number of replicates (n), $\mu$ normalized to $5^{\circ} \mathrm{C}$ by using a $Q_{10}$ of 2.8 $\left(\mu_{5^{\circ} \mathrm{C}}\right)$. and potential growth rate $\mathrm{d}^{-1}$ denved from the multiple regressions presented by Muller \& Geller (1993) normalized to $5^{\circ} \mathrm{C}\left(\mu_{\text {pot }\left(5^{\circ} \mathrm{Cl}\right)}\right)$

\begin{tabular}{|c|c|c|c|c|c|}
\hline Group/species & Volume $\left(\mu \mathrm{m}^{3}\right)$ & $\mu(\mathrm{SE})$ & $\mathrm{n}$ & $\mu_{5} \mathrm{C}$ & $\mu_{\text {pot }\left(5^{\circ} \mathrm{C}\right)}$ \\
\hline Mesodinium rubrum & 35000 & $0.327(0085)$ & 22 & 0.474 & \\
\hline Choreotrichs $10-20 \mu^{\mathrm{a}}$ & 1225 & $0.230(0.186)$ & 14 & 0.333 & 0.401 \\
\hline Choreotnchs $20-30 \mu \mathrm{m}^{\mathrm{s}}$ & 3925 & $0.163(0.164)$ & 10 & 0.236 & 0.293 \\
\hline Choreotrichs $30-40 \mu \mathrm{m}^{\mathrm{a}}$ & a 12375 & $0.121(0.129)$ & 8 & 0.175 & 0.215 \\
\hline Choreotrichs $>40{\mu \mathrm{m}^{\mathrm{a}}}^{\mathrm{a}}$ & 57825 & $0.066(0.227)$ & 4 & 0.096 & 0.142 \\
\hline Lohmaniella oviformis & 3200 & $0.318(0.070)$ & 20 & 0.461 & 0310 \\
\hline Tontonia sp. & 1225 & $0.224(0.073)$ & 4 & 0.325 & 0401 \\
\hline Balamon sp. & 2400 & $0.216(0.107)$ & 26 & 0.313 & 0.335 \\
\hline Strobilidium sp. & 5250 & 0.292 (0.191) & 4 & 0423 & 0.271 \\
\hline Euplotes-lıke cillate & 31200 & $0.021(0.043)$ & 4 & 0.030 & 0.167 \\
\hline
\end{tabular}

sented in Tables $5 \& 6$. In Fig. 7 the growth rates are plotted against cell volume. Data points present the mean value of maximum growth for each species. Growth rates decreased with cell volume according to the allometric equation $\mu=0.1248 \mathrm{~V}^{-0331}$ for ciliates $\left(\mathrm{r}^{2}=0.67\right)$ and $\mu=$ $0.0479 V^{-0164}$ for heterotrophic dinoflagellates $\left(r^{2}=0.78\right)$. Two data points were omitted from the regression between cillate growth rate and cell volume: Mesodinium rubrum, which is a functional autotrophic cilıate, and an Euplotes-like cillate, which was not considered a true pelagic species. During all but 2 growth incubations, the chlorophyll concentration increased with phytonlankton growth rates between 0 and $0.29 \mathrm{~d}^{-1}$ (mean $=0.13 \mathrm{~d}^{-1}$; data not shown).

Dally potential protozooplankton production, reflecting biomass and temperature, reached a peak of $360 \mathrm{mg} \mathrm{C} \mathrm{m} \mathrm{m}^{-2}$ $\mathrm{d}^{-1}$ in mid-August (Fig. 2D). Heterotrophic dinoflagellate potential production, on average, exceeded that of cili- 


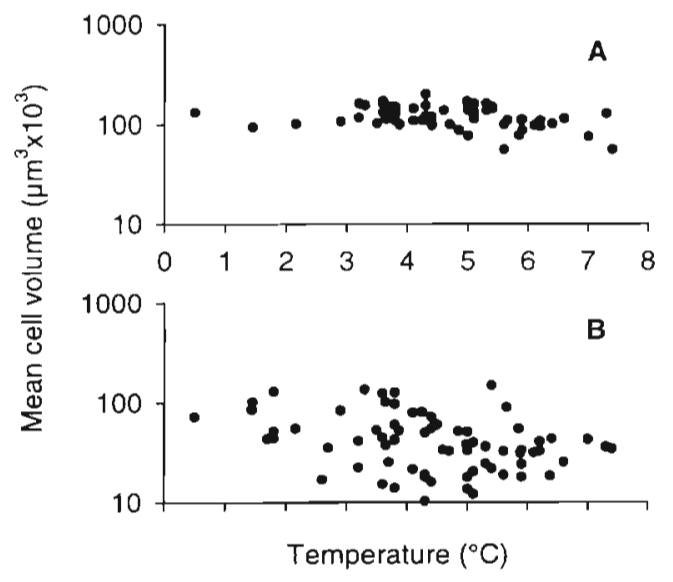

Fig. 6. Relationship between temperature and cell volume of (A) Laboea strobila and (B) Gyrodinium spirale. Note logarithmic scale

ates by a factor of 5 . The vertical distribution of the potential production followed the same pattern as the biomass, with elevated values in subsurface water, though the influence of temperature reduced the differences between production in surface and subsurface water (Fig. 8).

\section{DISCUSSION}

\section{Protozooplankton in an Arctic food web}

This study documents that both ciliates and heterotrophic dinoflagellates are significant components of the Arctic pelagic food web during the stratified icefree period after the spring bloom. Ciliate biomass remained relatively high, but larger heterotrophic dinoflagellates declined from the beginning of September and occurred mainly in mid-August.

Table 6. Growth of heterotrophic dinoflagellates. Maximum growth rate $\mathrm{d}^{-1}$ at $1.4^{\circ} \mathrm{C}(\mu)$, standard error (SE), number of replicates $(n)$. ESD: equivalent spherical diameter $(\mu m)$

\begin{tabular}{|lrrr|}
\hline Group/species & Volume $\left({\left.\mu \mathrm{m}^{3}\right)}^{3} \mu(\mathrm{SE})\right.$ & $\mathrm{n}$ \\
\hline Amphidinium crassum & 1375 & $0.378(0.379)$ & 12 \\
Amphidinium sphenoides & 525 & $0.366(0.240)$ & 10 \\
Gyrodinium glaucum & 4275 & $0.324(0.129)$ & 12 \\
Gyrodinium spirale & 49250 & $0.237(0.084)$ & 28 \\
Gyrodinium sp. & 7650 & $0.260(0.288)$ & 8 \\
Dinoflagellates, ESD 20-30. & 8181 & $0.276(0.097)$ & 22 \\
Dinoflagellates, ESD 30-40 & 22450 & $0.222(0.081)$ & 22 \\
Dinoflagellates, ESD 40-50 & 47713 & $0.151(0.016)$ & 2 \\
& & & \\
anaked dinoflagellates dominated by & Gymnodinium and \\
Gyrodinium spp. & & & \\
\end{tabular}

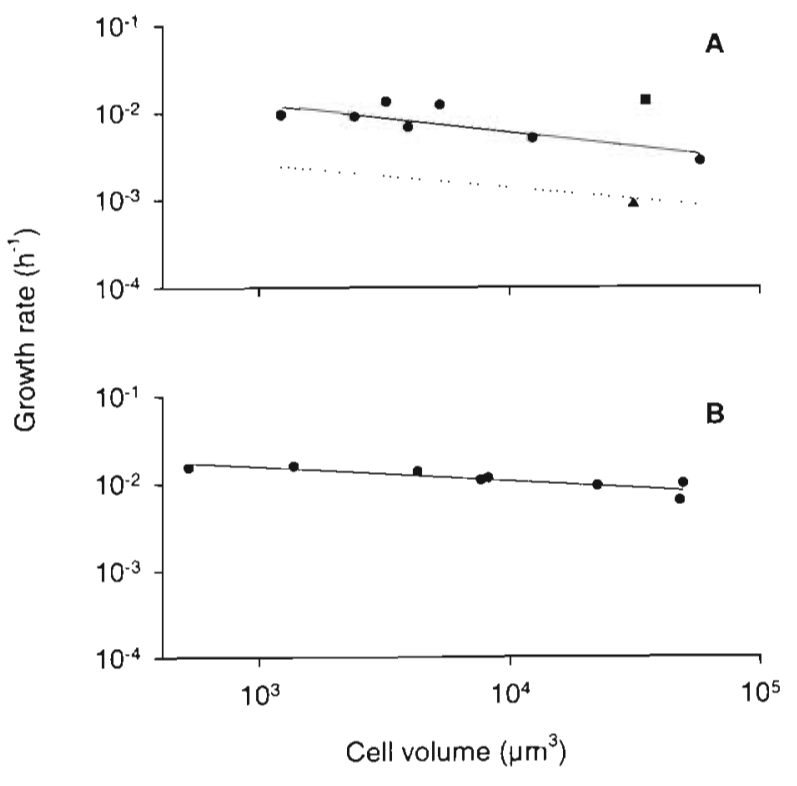

Fig. 7. Relationship between maximum growth rates (mean values) determined at $1.4^{\circ} \mathrm{C}$ and cell volumes of (A) 9 different species and size groups of ciliates and (B) 8 different species and size groups of heterotrophic dinoflagellates. (a) Mesodinium rubrum, (4) Euplotes-like ciliate. (...) 'Potential' maximum growth versus volume relationships calculated by the multiple regression provided by Müller \& Geller (1993)

Heterotrophic dinoflagellates dominated the protozooplankton and were primarily associated with summer subsurface blooms of diatoms, supporting the idea that heterotrophic dinoflagellate concentrations often are high when diatoms are abundant (Bursa 1961, Hansen 1991, Lessard 1991, Verity et al. 1993). The declining biomass in September reflects the decreasing diatom concentration. Heterotrophic dinoflagellate biomasses were comparable to those found during the spring diatom bloom in Disko Bay in 1992 (Nielsen \& Hansen 1995) and those associated with the spring and autumn phytoplankton blooms at lower latitudes (Smetacek 1981, Hansen 1991, Bralewska \& Witek 1995).

The abundance, biomass and species composition of the Disko Bay ciliate community were comparable to those reported from Arctic Canada (Paranjape 1987, 1988), the North Bering/Chukchi seas (Andersen 1988), the Greenland Sea (Putt 1990, Auf dem Venne 1994) and an earlier study from Disko Bay (Nielsen \& Hansen 1995), and not different from lower latitudes (Taniguchi 1984, Leakey et al. 1992, Pierce \& Turner 1992, Nielsen \& Kiørboe 1994, Edwards \& Burkill 1995).

Mixotrophic ciliates contributed on average $20 \%$ to the integrated ciliate biomass. This is comparable to other studies from different geographical areas 


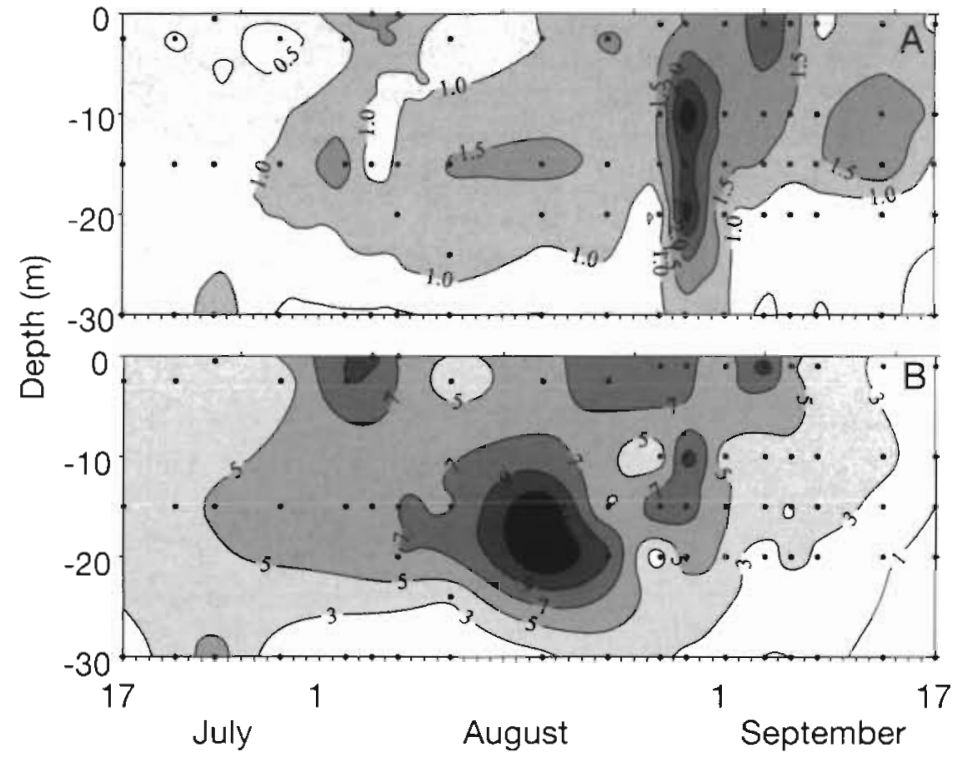

Fig. 8. Vertical and temporal distribution of temperature corrected potential (A) ciliate and (B) heterotrophic dinoflagellate production ( $\mu \mathrm{g} \mathrm{C}$ $\mathrm{i}^{-1} \mathrm{~d}^{-1}$ ) calculated from biomass and the volume-growth rate relationship obtained in the growth experiments. Dots indicate biomass sampling depths

(Stoecker et al. 1989, Putt 1990, Verity \& Vernet 1992 Bernard \& Rassoulzadegan 1994, Auf dem Venne 1994), and suggests that mixotrophy among ciliates is widespread also in the Arctic.

The relative cell size distribution of the ciliates and heterotrophic dinoflagellates revealed a similar seasonal trend, with an increasing abundance of small cells towards autumn. Also smaller cells were always most abundant in the 2 groups. However, in terms of biomass the relative cell size distribution of the ciliates and heterotrophic dinoflagellates differed. Small ciliates were always of minor importance compared to large ciliates. By contrast smaller heterotrophic dinoflagellate cells became the major heterotrophic dinoflagellate biomass component after the diatom subsurface blooms sedimented. Size selective predation of copepods preying on ciliates has been found to occur in laboratory experiments with suggested influences on population dynamics in natural waters (Stoecker \& Egloff 1987). These authors found higher clearance rates for adult Acartia tonsa on large ciliates compared to small ones. It might be that the dominance of small cells in the size structure of the protozooplankton community in Disko Bay was due to such size selective feeding behavior by the copopods. If this mechanism was the main factor regulating ciliate (and heterotrophic dinoflagellate) dynamics, however, one would have expected a cell size succession somewhat opposed to the one we observed. Large cells should have become more abundant in a relative sense fol- lowing the decline in total copepod biomass caused by the migration of the large Calanus spp. to their deep water hibernation refuge (Hansen et al. 1999). The large number of different copepod species and stages makes such an analysis complex. For example, as opposed to the adult A. tonsa, the nauplii of this same species had higher clearance for small than for large ciliates (Stoecker \& Egloff 1987) and late copepodid stages of Eucalanus pileatus did not prefer larger compared to smaller cells (Verity \& Paffenhöfer 1996). Still, it is possible that large and relatively slow-growing ciliates were regulated by the copepods as found in the Kattegat, Denmark (Nielsen \& Kiørboe 1994), leading to low abundance.

\section{Cell size in relation to temperature}

Laboratory studies (James \& Read 1957, Fenchel 1968, Lee \& Fenchel 1972) have shown that the ciliates Tetrahymena, Uronema and Euplotes increase in cell volume at low temperatures. Such an increase was evident also in Laboea strobila in the present study, when comparing its mean cell volumes with the temperatures observed in Disko Bay. Furthermore, a similar increase in cell volume was found for the dominant heterotrophic dinoflagellate Gyrodinium spirale. Both relationships reflect large variation, but, to our knowledge, represent the first attempt to establish and document such a relationship for in situ populations of protozooplankton. The different food regimes encountered under natural growth conditions complicate the cell size versus temperature relationship due to the potential influence of food quantity and quality on predator cell size. This is particularly true for $G$. spirale, in which cell shape shifts when it is offered large prey items (Hansen 1992). Recalling that cell volume estimates of $L$. strobila and $G$. spirale are based on fixed length-width relationships, this implies potentially large errors in the cell volume estimation. Even though the L. strobila length-width relationship seems rather constant compared to $G$. spirale, both species were potentially affected by food since regression analyses show significant relationships between temperature and chl a (Table 7). In order to evaluate the effect of food on cell size, a regression analysis on chl a and mean cell volumes was conducted. In fact, cell volume of $G$. spirale was significantly correlated with chl a (Table 7), indicating covariation of cell volume with both temperature and potential food. 
Table 7. Regression data for chl a versus temperature and the 2 dominant protozooplankton species versus potential food availability (chl a). ns: non significant

\begin{tabular}{|cccc|}
\hline & $\begin{array}{c}\text { Temp. } \\
\left({ }^{\circ} \mathrm{C}\right)\end{array}$ & $\begin{array}{c}\text { Laboea strobila } \\
\left(\mu \mathrm{g} \mathrm{C} \mathrm{l}^{-1}\right)\end{array}$ & $\begin{array}{c}\text { Gyrodinium spirale } \\
\left(\mu \mathrm{g} \mathrm{C} \mathrm{l}^{-1}\right)\end{array}$ \\
\hline Chl $\mathrm{a}$ & $\mathrm{r}^{2}=0.22$ & $\mathrm{r}^{2}=0.04$ & $\mathrm{r}^{2}=0.22$ \\
$\left(\mu \mathrm{g} \mathrm{l}^{-1}\right)$ & $\mathrm{p}<0.001$ & $\mathrm{p}>0.5^{\mathrm{ns}}$ & $\mathrm{p}<0.001$ \\
& $\mathrm{n}=72$ & $\mathrm{n}=61$ & $\mathrm{n}=72$ \\
\end{tabular}

\section{Growth in cold-water ecosystems}

If the concentration of $<11 \mu \mathrm{m} \mathrm{chl} \mathrm{a}$ is used as an estimate of ciliate food availability and the C:chl a conversion factor of 43 (Nielsen \& Hansen 1999) is applied, then the initial food concentration in the growth experiments was $28 \pm 9 \mu \mathrm{g} \mathrm{Cl}^{-1}$ (mean $\pm \mathrm{SD}$ ). Heterotrophic nanoflagellates which also potentially contributed to the total ciliate food availability further add a biomass of $0.54 \pm 0.3 \mu \mathrm{g} \mathrm{C} \mathrm{I}^{-1}$ to this value. Threshold concentrations for growth from 7.5 to $325 \mu \mathrm{g} \mathrm{C} \mathrm{l}^{-1}$ have been measured for Strobilidium and Strombidium species (see Table 4 in Montagnes 1996). This implies that some species were possibly food limited. In fact, we did not succeed in measuring growth of large ciliates. They might have been starving due to higher threshold concentrations. It should be mentioned that alternative food sources (e.g. bacteria) which potentially contributed to the total ciliate food availability were not included in the above considerations. Mesodinium rubrum was the fastest growing ciliate. Apparently this autotrophic ciliate was superior to the heterotrophic and mixotrophic ciliates during the incubations. Montagnes (1996) analyzed the predictability of multiple regressions provided by Montagnes et al. (1988), Müller \& Geller (1993) and Nielsen \& Kiørboe (1994), who all used temperature and cell volume to predict maximum ciliate growth. By comparing with laboratory-derived maximum growth estimates, he concluded that the equation provided by Müller \& Geller (1993) was the best predictor of growth in Strobilidium and Strombidium species. Accordingly, we have chosen this equation to represent the maximum cellvolume based growth-rate relationship. As observed from Fig. 7A this implies that we may have overestimated ciliate growth as our growth rates were significantly larger than the potential rates $(p<0.0001$; see Fig. 7). The discrepancy may also reflect that the equation of Müller \& Geller (1993) inadequately predicts growth rates at low temperatures. Furthermore, the conclusion drawn by Montagnes (1996) regarding the superiority of the Müller \& Geller equation is largely based on comparisons with growth rates obtained at the high temperature end $\left(17 \pm 6^{\circ} \mathrm{C}\right)$. When using the
Müller \& Geller equation to predict growth rates at $5^{\circ} \mathrm{C}$, it gave values almost similar to our maximum growth rates transformed from 1.4 to $5^{\circ} \mathrm{C}$ applying a $Q_{10}$ of 2.8 (Table 5 ; the calculated mean community growth rates were similar). Also, the community growth rate of $0.201 \mathrm{~d}^{-1}$ (at $1.4^{\circ} \mathrm{C}$ ) was not very different from $0.135 \mathrm{~d}^{-1}$ estimated for phagotrophic ciliates within the sea ice in Resolute Passage, Canadian High Arctic (presumably at about $-1.8^{\circ} \mathrm{C}$ ime- Sgando et al. 1997). Arctic protozoans may consist of subspecies or clones which have adapted to an extreme environment. This makes it difficult to predict their growth rates from data obtained at higher temperatures. On this basis there is clearly a need for conducting more ciliate growth experiments in cold waters (where max. temperatures $<\sim 5^{\circ} \mathrm{C}$ ) to improve the very convenient predictive tool provided by multiple regressions as those noted above in for example the construction of food-web models.

In evaluating our maximum heterotrophic dinoflagellate growth rates we have made a comparison with the only other low-temperature growth estimate for heterotrophic dinoflagellates available. Applying the cold-water growth data of Bjørnsen \& Kuparinen (1991) for a small gymnodinoid dinoflagellate from the Southern Ocean and the volume-based growth rate equation from the present study revealed that the obtained growth rates in this study are not severely overestimated (Table 8). Overall the growth experiments showed that the ciliate and heterotrophic dinoflagellate growth rates observed in Disko Bay at times were close to maximum rates, stressing these organisms' potential significance as grazers and trophic intermediates in the food web.

\section{Ecological impact and role in the food web}

Ciliates have often been thought of as the 'typical' microheterotrophic protist grazers on phytoplankton even though heterotrophic dinoflagellate biomass often equals that of ciliates in the plankton (Sherr \& Sherr 1994). Based on the biomass and the cell volumemaximum growth rate relationship obtained in this study, heterotrophic dinoflagellates seem to be even

Table 8. Maximum growth rate $\mathrm{d}^{-1}$ for a heterotrophic Gymnodinium sp. (volume $1250 \mu^{3}$ ) obtained from quasinatural microcosms experiments conducted at $1^{\circ} \mathrm{C}$ (Bjernsen \& Kuparinen 1991) compared with the growth rate predicted from the volume-growth relationship obtained in this study

$\begin{array}{ll}\text { Bjørnsen \& Kuparinen (1991) } & 0.31 \\ \text { This study } & 0.49\end{array}$


more significant herbivorous consumers than do ciliates. Thus, the main part of the protozooplankton production (and ingestion) was due to heterotrophic dinoflagellates. Their production on average exceeded ciliates by a factor of 5 . Apart from the general higher biomass of heterotrophic dinoflagellates, this could be due to higher specific community production, at least during the second half of the study period, where the heterotrophic dinoflagellate biomass was composed of smaller cells (Fig. 5B,D). Also, the heterotrophic dinoflagellate scaling exponent of -0.16 compared to that of the ciliates of -0.33 caused a relatively fast decrease in growth rates of ciliates with size, thereby amplifying the difference in production between the 2 groups, particularly at large cell sizes. Finally, we simply obtained higher growth rates for heterotrophic dinoflagellates compared to ciliates (Tables $5 \& 6$ ). This is in contrast to other studies mainly from the laboratory which report heterotrophic dinoflagellate maximum growth rates lower than planktonic ciliates of similar size (Hansen 1992, Sherr \& Sherr 1994). Even though there might be a discrepancy between maximum growth rates obtained in the laboratory and under field conditions (e.g. because of suboptimal diet in the laboratory studies compared with the field), it is not possible to evaluate such potential discrepancy based on this study alone due to the large variation in the growth estimates. More growth studies particularly at low temperatures are certainly needed.

Recently, attention has been given to the heterotrophic dinoflagellates as studies suggest that they occupy a different niche with regard to prey than predicted by the concept of the microbial loop. A linear size ratio between dinoflagellate predators and their optimal prey size of 1:1 has been proposed (Hansen et al. 1994), far from the general assumption of 10:1 (Azam et al. 1983). An implication of this predator:prey relationship is that small $(<20 \mu \mathrm{m})$ heterotrophic dinoflagellates will compete with ciliates for nanoplankton prey, while heterotrophic dinoflagellates $>20 \mu \mathrm{m}$ ingest prey which in general are too large for ciliates (Hansen 1992). Dinoflagellates $>20 \mu \mathrm{m}$ therefore are likely to compete primarily with copepods for food, and not with ciliates and other heterotrophic protists in the pelagic food web. In the present study the majority of the heterotrophic dinoflagellate biomass consisted of Gymnnodinium and Gyrodinium spp. $>20 \mu \mathrm{m}$, indicating a significant grazing impact on relatively large prey items such as the diatoms in the subsurface water and ciliates; indeed when comparing estimates of potential heterotrophic dinoflagellate and copepod grazing, it shows that heterotrophic dinoflagellates exert a major impact (Hansen et al. 1999).

The calculated potential protozooplankton production from July to September 1994 was $200 \pm 80 \mathrm{mg} \mathrm{C}$ $\mathrm{m}^{-2} \mathrm{~d}^{-1}$ (mean $\left.\pm \mathrm{SD}\right)$. As the biomass was $692 \pm 295 \mathrm{mg}$ $\mathrm{C} \mathrm{m}^{-2}$, an average turnover rate for the protozooplankton community of $0.29 \mathrm{~d}^{-1}$ could be calculated during late summer in Disko Bay. This P/B ratio corresponds to a generation time of $-3.5 \mathrm{~d}$ for an 'average protozooplankton organism'. In the second part of the study in which data on primary production are available (Nielsen \& Hansen 1999) the estimated protozooplankton production was $152 \pm 71 \mathrm{mg} \mathrm{C} \mathrm{m}^{-2} \mathrm{~d}^{-1}$ compared to a primary production of $154 \pm 66 \mathrm{mg} \mathrm{C} \mathrm{m}^{-2} \mathrm{~d}^{-1}$. By assuming a carbon growth yield of $33 \%$ and a pure autotrophic diet of ciliates and heterotrophic dinoflagellates, protozooplankton on average could remove $44 \%$ of the phytoplankton standing stock and $362 \%$ of primary production daily. By including the heterotrophic nanoflagellates (ignoring bacteria), protozooplankton would still potentially be able to remove $>40 \%$ of their food $\mathrm{d}^{-1}$. Thus, even though the protozooplankton potentially were able to grow at their maximum rates, probably not all of them did so in situ, as they would otherwise graze down their prey in a few days, which they did not. Rather, as protozooplankton are able to ingest each other, cannibalism reduced grazing pressure, allowing prey organisms to increase their concentration slightly, and thus serve again as food (Paffenhöfer 1998). In Disko Bay therefore it could be assumed that the protozooplankton experienced an ever shifting variation in growth rate between low or even negative and maximum.

\section{Dynamics and regulation}

High phytoplankton concentrations were associated with the pycnocline throughout the study. A pronounced response in protozooplankton biomass was observed following this phytoplankton distribution. The presence of a large protozooplankton biomass in subsurface water probably reflects the higher food concentrations encountered in these layers, but food may not have been the sole factor influencing the ciliates' and heterotrophic dinoflagellates' vertical structure. The vertical distribution pattern of the protozooplankton was probably influenced by the copepods also. In general the clearance of calanoid copepods increases with decreasing food concentration (Frost 1972). Moreover, food retention efficiency increases with increasing food size (Frost 1977). In our case, with small phytoplankton being dominant and in low concentration in the surface water and large phytoplankton being dominant and in high concentration in the subsurface water, one could assume that the copepods influenced these environments very differently. This would imply that the copepod clearance on protozooplankton was relatively low in subsurface water and 
hence predation on ciliates and heterotrophic dinoflagellates probably was less significant in these layers (Fessenden \& Cowles 1994).

During the summer the diatom subsurface blooms declined and phytoplankton changed towards a nanoplankton dominated community (Nielsen \& Hansen 1999) with pronounced implications for the ciliates and heterotrophic dinoflagellates. While the large heterotrophic dinoflagellates declined after the diatom subsurface blooms disappeared, the ciliates obtained a high biomass. The heterotrophic dinoflagellates declined after the chl a concentrations decreased to $<1 \mu \mathrm{g} \mathrm{l}^{-1}$, corresponding to $43 \mu \mathrm{g} \mathrm{Cl}^{-1}$ (Figs. 1 \& 3C,D), supporting the suggested higher food threshold concentrations for growth of these organisms compared to ciliates (Hansen 1992).

The change in the composition of the protozooplankton community coincided with the migration to the deep water of the large Calanus spp. Since Calanus spp. formed most of the copepod biomass, the grazing pressure was greatly reduced after they left the euphotic zone. Until mid-August the copepod community had an estimated grazing potential of $-20 \%$ of the water column $\mathrm{d}^{-1}$, which decreased to $\sim 3 \% \mathrm{~d}^{-1}$ in September (Hansen et al. 1999). Accordingly, the increasing ciliate population in late August could be attributed to a reduced predation pressure. At this time most heterotrophic dinoflagellates were probably food limited and not affected by the released top-down regulation.

There were still some heterotrophic dinoflagellates growing in September, however, as evident from the growth experiments. Apparently, the low phytoplankton concentrations were able to sustain a small population of heterotrophic dinoflagellates relying on smallscale patches of phytoplankton and ciliates as food.

\section{Conclusion}

The prominent late summer feature of enhanced phytoplankton concentrations in subsurface water associated with the pycnocline was reflected in the succeeding heterotrophic links in the food chain. Particularly, heterotrophic dinoflagellates, which were the most significant heterotrophic protist in terms of biomass, showed vertical profiles with pronounced subsurface maxima concurrently with the phytoplankton. Apart from elevated biomasses of heterotrophic dinoflagellates and ciliates, bacteria and nanoflagellate patches of high biomass were also observed here (Nielsen \& Hansen 1999). Since these patches of high phytoplankton concentration provided a potential shelter from e.g. copepod and fish larvae predation compared with the nutrient depleted surface water, it is important that the subsurface protist communities are included in future studies of Arctic carbon cycling.

Acknowledgements. We greatly acknowledge Hanne Ferdinand, Dorte Grastrup Hansen, Jens Larsen and Birgit Soeborg for technical assistance. Jacob Larsen identified the naked heterotrophic dinoflagellates from live samples. We are grateful to the crew of RV 'Porsild', the 'plankton group' and Helge A. Thomsen, University of Copenhagen, for help during sampling and The Board of Arctic Station for providing excellent facilities. We thank Per Juel Hansen, David Montagnes, Alf Skovgaard and Jefferson Turner for critical comments on an earlier version of the manuscript. The investigation was financially supported by The Commission for Scientific Research in Greenland (j.no.5.111/80), Beckett's Foundation and The Danish National Research Council (No 9501038).

\section{LITERATURE CITED}

Andersen OG (1981a) The annual cycle of temperature, salinity, currents and water masses in Disko Bugt and adjacent waters, West Greenland. Medd Grønl 5

Andersen OG (1981b) The annual cycle of phytoplankton, primary production and hydrography in the Disko Bugt area, West Greenland. Medd Grønl 6

Andersen P (1988) The quantitative importance of the 'microbial loop' in the marine pelagic: a case study from the North Bering/Chukchi Seas. Arch Hydrobiol Beih Ergebn Limnol 31:243-251

Auf dem Venne H (1994) Zur Verbreitung und okologischen Bedeutung planktischer Ciliaten in zwei verschiedenen Meeresgebieten: Grönlandsee und Ostsee. Dissertation, Christian-Albrechts-Universität zu Kiel

Azam F, Fenchel T, Field JG, Gray JS, Meyer-Reil LA, Thingstad $F$ (1983) The ecological role of water-column microbes in the sea. Mar Ecol Prog Ser 10:257-263

Berggreen U, Hansen B, Kiørboe T (1988) Food size spectra, ingestion and growth of the copepod Acartia tonsa during development: implications for determination of copepod production. Mar Biol 99:341-355

Bernard C, Rassoulzadegan F (1994) Seasonal variations of mixotrophic ciliates in the northwest Mediterranean Sea. Mar Ecol Prog Ser 108:295-301

Bjørnsen PK, Kuparinen J (1991) Growth and herbivory by heterotrophic dinoflagellates in the Southern Ocean, studied by microcosm experiments. Mar Biol 109:397-405

Bralewska J, Witek Z (1995) Heterotrophic dinoflagellates in the ecosystem of the Gulf of Gdansk. Mar Ecol Prog Ser $117: 241-248$

Burkill PH (1982) Ciliates and other microplankton components of a nearshore food web: standing stocks and production processes. Ann Inst Océanogr 58:335-350

Burkill PH, Edwards ES, John AWG, Sleigh MA (1993) Microzooplankton and their herbivorous activity in the northeastern Atlantic Ocean. Deep-Sea Res II 40:479-493

Bursa AS (1961) The annual oceanographical cycle at Igloolik in the Canadian Arctic. II. The phytoplankton. J Fish Res Bd Can 18:563-615

Dodge JD (1985) Marine dinoflagellates of the British Isles. Her Majesty's Stationery Office, London

Dolan JR (1991) Guilds of ciliate microzooplankton in the Chesapeake Bay. Estuar Coast Shelf Sci 33:137-152

Drebes G (1974) Marine Phytoplankton, eine Auswahl. der Helgoländer Planktonalgen (Diatomeen, Peridineen). Georg Thieme Verlag, Stuttgart 
Edler L (1979) Recommendations for marine biological studies in the Baltic sea. Baltic Mar Biol Publ 5:1-38

Edwards ES, Burkill PH (1995) Abundance, biomass and distribution of microzooplankton in the Irish Sea. J Plankton Res 17:771-782

Fenchel T (1968) The ecology of marine microbenthos III. The reproductive potential of ciliates. Ophelia 5:123-136

Fessenden L, Cowles TJ (1994) Copepod predation on phagotrophic ciliates in Oregon waters. Mar Ecol Prog Ser 107: 103-111

Frost BW (1972) Effects of size and concentration of food particles on the feeding behavior of the marine planktonic copepod Calanus pacificus. Limnol Oceanogr 17:805-815

Frost BW (1977) Feeding behavior of Calanus pacificus in mixtures of food particles. Limnol Oceanogr 22:472-491

Gitron GL, Lynn DH (1989) Estimates of in situ population growth rates of four tintinnine ciliate species near Kingston Harbour, Jamaica. Estuar Coast Shelf Sci 29:1-10

Haas LW (1982) Improved epifluorescence microscopy for observing planktonic micro-organisms. Ann Inst Océanogr Paris 58:261-266

Hansen B, Bjornsen PK, Hansen PJ (1994) The size ratio between planktonic predators and their prey. Limnol Oceanogr 39:395-403

Hansen $B$, Christiansen S, Pedersen G (1996) Plankton dynamics in the marginal ice zone of the central Barents Sea during spring: carbon flow and structure of the grazer food chain. Polar Biol 16:115-128

Hansen BW, Nielsen TG, Levinsen H (1999) Plankton community structure and carbon cycling on the western coast of greenland during the stratified summer situation. III. Mesozooplankton. Aquat Microb Ecol 16:233-249

Hansen PJ (1991) Quantitative importance and trophic role of heterotrophic dinoflagellates in a coastal pelagial food web. Mar Ecol Prog Ser 73:253-261

Hansen PJ (1992) Prey size selection, feeding rates and growth dynamics of heterotrophic dinoflagellates with special emphasis on Gyrodinium spirale. Mar Biol 114:327-334

Hansen PJ, Nielsen TG, Kaas H (1995) Distribution and growth of protists and mesozooplankton during a bloom of Chrysochromulina spp. (Prymnesiophyceae, Prymnesiales). Phycologia 34:409-416

Hansen PJ, Bjørnsen PK, Hansen BW (1997) Zooplankton grazing and growth: scaling within the $2-2000 \mu \mathrm{m}$ body size range. Limnol Oceanogr 42:687-704

James TW, Read CP (1957) The effect of incubation of temperature on the cell size of Tetrahymena pyriformis. Exp Cell Res 13:510-516

Jespersen AM, Christoffersen K (1987) Measurements of chlorophyll a from phytoplankton using ethanol as extraction solvent. Arch Hydrobiol 109:445-454

Kahl A (1932) Urtiere oder Protozoa. I. Wimpertiere oder Ciliata (Infusoria). 3. Spirotricha. In: Dahl F (ed) Die Tierwelt Deutschlands und der angrenzenden Meeresteile. Gustav Fischer Verlag, Jena

Krainer K, Foissner W (1990) Revision of the genus Askenasia Blochmann, 1895, with proposal of two new species, and description of Rhabdoaskenasia minima n. g., n. sp. (Ciliophora, Cyclotrichida). J Protozool 37:414-427

Laurion I, Demers S, Vézina AF (1995) The microbial food web associated with the ice algal assemblage: biomass and bacteriovory of nanoflagellate protozoans in Resolute Passage (High Canadian Arctic). Mar Ecol Prog Ser 120:77-87

Laval-Peuto M. Febvre M (1986) On plastid symbiosis in Tontonia appendiculariformis (Ciliophora, Oligotrichina) BioSyst 19:137-158

Leakey RJG, Burkill PH, Sleigh MA (1992) Planktonic ciliates in Southampton Water: abundance, biomass, production and role in pelagic carbon flow. Mar Biol 114:67-83

Leakey RJG, Burkill PH, Sleigh MA (1994) Ciliate growth rates from Plymouth Sound: comparison of direct and indirect estimates. J Mar Biol Assoc UK 74:849-861

Lee CC, Fenchel T (1972) Studies on ciliates associated with sea ice from Antarctica II. Temperature responses and tolerances in ciliates from antarctic, temperate and tropical habitats. Arch Protistenk 114:237-244

Leegaard C (1915) Untersuchungen über einige Planktonciliaten des Meeres. Nytt Mag Naturvidensk 53:1-37

Lessard EJ (1991) The trophic role of heterotrophic dinoflagellates in diverse marine environments. Mar Microb Food Webs 5:49-58

Lessard EJ, Brownlee DC, Sellner K, Caron DA (1988) Role of microzooplankton biomass, growth, and grazing in plankton dynamics in Chesapeake Bay. EOS 69:1103

Lynn DJ, Montagnes DJS (1988) Taxonomic descriptions of some conspicuous species of strobilidiine ciliates (Ciliophora: Choreotrichida) from the Isles of Shoals, Gulf of Maine. J Mar Biol Assoc UK 68:639-658

Lynn DJ, Montagnes DJS, Small EB (1988) Taxonomic description of some conspicuous species in the family Strombidiidae (Ciliophora: Oligotrichida) from the Isles of Shoals, Gulf of Maine. J Mar Biol Assoc UK 62 $252-259$

Lynn DJ, Montagnes DJS, Dale T, Gilron GL, Strom SL (1991) A reassessment of the genus Strombidinopsis (Ciliophora Choreotrichida) with descriptions of four new planktonic species and remarks on its taxonomy and phylogeny. J Mar Biol Assoc UK 71:597-612

McManus GB, Fuhrman JA (1986) Photosynthetic pigment in the ciliate Laboea strobila from Long Island Sound, USA. J Plankton Res 8:317-327

Montagnes DJS (1996) Growth responses of planktonic ciliates in the genera Strobilidium and Strombidium. Mar Ecol Prog Ser 130:241-254

Montagnes DJS, Lynn DH, Roff JC, Taylor WD (1988) The annual cycle of heterotrophic planktonic ciliates in the waters surrounding the Isles of Shoals, Gulf of Maine: an assessment of their trophic role. Mar Biol 99:21-30

Müller H, Geller W (1993) Maximum growth rates of aquatic ciliated protozoa: the dependence on body size and temperature reconsidered. Arch Hydrobiol 126:315-327

Nielsen GE, Bresta AM (1984) Guidelines for measurements of phytoplankton primary production. Baltic Mar Biol Publ $1: 1-23$

Nielsen TG, Hansen B (1995) Plankton community structure and carbon cycling in Arctic West Greenland during and after the sedimentation of a diatom bloom. Mar Ecol Prog Ser 125:239-257

Nielsen TG, Hansen B (1999) Plankton community structure and carbon cycling on the western coast of Greenland during the stratified summer situation. I. Hydrography, phytoplankton and bacterioplankton. Aquat Microb Ecol 16: $205-216$

Nielsen TG, Kiørboe T (1994) Regulation of zooplankton biomass and production in a temperate, coastal ecosystem. 2 Ciliates. Limnol Oceanogr 39:508-519

Paffenhöfer GA (1998) Heterotrophic protozoa and small metazoa: feeding rates and prey-consumer interactions. J Plankton Res 20:121-133

Paranjape MA (1987) Grazing by microzooplankton in the eastern Canadian Arctic in summer 1983. Mar Ecol Prog Ser 40:239-246

Paranjape MA (1988) Microzooplankton in Lancaster Sound (eastern Canadian Arctic) in summer: biomass and distrib. 
ution. Deep-Sea Res 35:1547:1563

Pérez MT, Dolan JR, Fukai E (1997). Planktonic oligotrich ciliates in the NW Mediterranean: growth rates and consumption by copepods. Mar Ecol Prog Ser 155:89-101

Pierce RW, Turner JT (1992) Ecology of planktonic ciliates in marine food webs. Rev Aquat Sci 6:139-181

Porter KG, Feig YS (1980) The use of DAPI for identifying and counting aquatic microflora. Limnol Oceanogr 25: 943-948

Putt M (1990) Abundance, chlorophyll content and photosynthetic rates of ciliates in the Nordic Seas during summer. Deep-Sea Res 37:1713-1731

Riemann B, Sørensen HM, Biørnsen PK, Horsted SJ, Jensen LM, Nielsen TG, Sondergaard M (1990) Carbon budgets of the microbial food web in estuarine enclosures. Mar Ecol Prog Ser 65:159-170

Sherr BF, Sherr EB, Pedrós-Alió C (1989) Simultaneous measurement of bacterioplankton production and protozoan bacterivory in estuarine water. Mar Ecol Prog Ser 54:209-219

Sherr EB, Sherr BF (1994) Bacterivory and herbivory: key roles of phagotrophic protists in pelagic food webs. Microb Ecol 28:223-235

Sherr EB, Sherr BF, Fallon R.D, Newell SY (1986) Small aloricate ciliates as a major component of the marine heterotrophic nanoplankton. Limnol Oceanogr 31:177-183

Sherr EB, Rassoulzadegan F, Sherr BF (1989) Bacterivory by pelagic choreotrichous ciliates in coastal waters of the NW Mediterranean Sea. Mar Ecol Prog Ser 55:235-240

Sime-Ngando T, Gosselin M, Juniper K, Levasseur M (1997). Changes in sea-ice phagotrophic microprotists $(20-200$ $\mu \mathrm{m})$ during the spring algal bloom, Canadian Arctic Archipelago. J Mar Syst 11:163-172

Editorial responsibility: John Dolan,

Villefranche-sur-Mer, France
Smetacek V (1981) The annual cycle of protozooplankton in the Kiel Bight. Mar Biol 63:1-11

Stoecker DK, Capuzzo JM (1990) Predation on protozod: its importance to zooplankton. J Plankton Res 12:891-908

Stoecker DK, Egloff DA (1987) Predation by Acartia tonsa Dana on planktonic ciliates and rotifers. J Exp Mar Biol Ecol 110:53-68

Stoecker DK, Davis LH, Provan A (1983) Growth of Favella sp. (Ciliata: Tintinnina) and other microzooplankters in cages incubated in situ and comparison to growth in vitro. Mar Biol 75:293-302

Stoecker DK, Taniguchi A, Michaels AE (1989) Abundance of autotrophic, mixotrophic and heterotrophic planktonic ciliates in shelf and slope waters. Mar Ecol Prog Ser 50: 241-254

Taniguchi A (1984) Microzooplankton biomass in the Arctic and Subarctic Pacific Ocean in summer. Memoirs of the National Institute of Polar Research, Special Issue No. 32. Proc Sixth Symp Polar Biol, p 63-76

Thomsen HA (ed) (1992) Plankton i de indre danske farvande. Miljøstyrelsen

Verity PG (1986) Growth rates of natural tintinnid populations in Narragansett Bay. Mar Ecol Prog Ser 29:117-126

Verity PG, Vernet M (1992) Microzooplankton grazing, pigments, and composition of plankton communities during late spring in two Norwegian fjords. Sarsia 77:263-274

Verity PG, Stoecker DK, Sieracki ME, Burkill PH, Edwards ES, Tronzo CR (1993) Abundance, biomass and distribution of heterotrophic dinoflagellates during the North Atlantic spring bloom. Deep-Sea Res II 40:227-244

Verity PG, Paffenhöfer GA (1996) On assessment of prey ingestion by copepods. J Plankton Res 18:1767-1779

Submitted: October 30, 1997; Accepted: July 17, 1998 Proots received from author(s): February 22, 1999 